\title{
わが国ライフサイエンス研究のこれからの方向
}

\author{
水 島 裕
}

Jpn. J. Clin. Immun., 23 (6) : 477〜480, 2000.

\section{The future trend of life science researches in Japan}

\author{
Yutaka Mizushima
}

St. Marianna University, Institute of Medical Science

Emeritus Professor and Director

Member of the House of Councillors

ライフサイエンスは研究としては 21 世紀の花形と なり，産業としても 21 世紀のリーディング産業とな ろう. ライフサイエンス研究がなぜ重要かというと, 一つは科学の発展のみならず，人類の福祉に貢献する からである．第二は現在低迷している日本の産業の発 展の一翼を担うからである. 現在日本のライフサイエ ンス産業の規模は 1 兆円強であるが, 政府は 2010 年 には25 兆円になることを想定している．21 世紀はオ ーダーメイド医療の時代になると予想されるが，これ もライフサイエンス研究の成果次第である。ここ 10 年，つまり 1990 年代を先進欧米諸国と比較し振り返 ると,ライフサイエンスの研究て大きく水を開けられ てしまった，すなわち日本にとっては失われた 10 年 といってもよいくらいである.ようやくこのことに気 がついた政官学産は，ミレニアムプロジェクトとし て，2000 年からライフサイエンスの研究を強く推進 することになった。

まず，ライフサイエンスや医薬品の研究・産業が果 たして予想どおり発展するだろうか，足腰の弱い日本 の科学から画期的な発明・発見が果たして生まれる か？ 実用化のスピードにもっとも影響する環境整備 は大丈夫か？現在の環境整備を考えると，2010 年 にライフサイエンス産業が 25 兆円の規模まで拡大す

聖マリアンナ医科大学 名誉教授, 参議院議員
ることはとても無理であろう．政府は昨年度「大学等 技術移転促進法（TLO 法案)」を制定し，さらに本年 度「産業技術力強化法案」を成立させた。その概略を 表 1，表 2 に示した。 文部省も研究費の使用項目に関 して流動制度を新設し，大学の研究を産業へ移転する ことに力を入れている，また，現在私が委員長となり 本国会成立をめざしている「ヒトに関するクローン技 術等の規制に関する法律案」(表 3）についても紹介 した。

次に本年 4 月よりスタートしたミレニアムプロジェ クトについて述べたが, このプロジェクトの大きな柱 はライフサイエンスであり, 図 1 に示したようにゲ, ムプロジェクトを中心に再生医学その他にも力を入れ ている. 前者はポストシークエンスとして病因遺伝子 の解明，それに基づく画期的創薬に期待が持たれてい るので，その成果を一部紹介した，SNPs プロジェク 卜も大きな柱である. SNPs，すなわちわずか一塩基 が異なる多型をタイピングすることで遺伝的素因を知 ることができる。つまり，どのような疾患になりやす いかや早期診断を可能にし, 薬郕反応性 SNPS の解 明・検查により薬剤の効果や副作用を前もって知るこ とができる，いわばオーダーメイド医療の確立が近い 将来のものになると考えられている.すでに $\beta$ ブロ ッカーや抗がん薬について得られているデータを紹介 した.つまり，今後の遺伝子診断は図 2 に示したごと 
表 1 産業技術力強化法

平成 12 年 4 月 20 日施行

1. 目的

産業技術力強化へ向けた環境の整備を図るもの.

2. 法律の内容

（1）大学の研究活動の活性化のための環境整備

(1) 民間から国公立大学への資金受け入れ円滑化

(2) 産学連擭のための大学教官への研究助成制度の 創設（平 $12: 26$ 億円）

(3) 大学教官の特許料等の軽减

(2) 研究成果の段業への移転の円滑化

(1) 公務員の民間企業役員の兼業規制緩和

(2) TLOの国有財産の無償使用措置

（3）民間における技術の「実用化」に向けた環境整備： 助成金, 特許料軽隇

（4）その他
表 2 TLO 法

Technology Licensing Organization （大学等に扔ける技術に関する研究成果の民間事業者への 移転の促進に関する法律)

平成 10 年 8 月 1 日法律施行

1. 事業の内容

(1) 大学における企業化しうる研究成果の発掘・評 価・選別

(2) 研究成果に関する特許権等の取得・維持・保全

(3) 企業への移転等によって得た収入の配分, など

2. 実施計画の承認

適切で見込みがあれぱ，通産大臣及び文部大臣は計画 を承認し, 技術移転機関（承認 TLO）に対し産業基 盤整備基金による支援を行う。

表 3 ヒトに関するクローン技術等の規制に関する法律案（抜粋）

第一 目的

クローン技術等のうちクローン技術又は特定融合・集合技術により作成される肧を人又は動物の胎内に移植するこ とを禁止するとともに，クローン技術等による胚の作成，锤受及び輸入を規制し，その他当該胚の適正な取扱いを確 保するための措置を講ずることにより個体の生成の防止並びに個体の人為による生成の規制を図り，もって社会及び 国民生活と調和のとれた科学技術の発展を期することを目的とすること.

第二 定義

一 肧 一の細胞（生殖細胞を除く）又は細胞群であって，そのまま人又は動物の体内において発生の過程を経るこ

とにより一の個体に成長する可能性のあるもののうち，胎盤の形成を開始する前のものをいうものとすること．

二 生殖細胞

三未受精卵

四 体細胞

第三 禁止行為

何人も，人クローン胚，上卜動物交雑胚，ヒト性融合胚又は七ト性集合胚を人又は動物の胎内に移植してはならな いものとすること.

1) ヒトゲノム

・ シークエンス解析

. 有用遺伝子の機能解明

- SNPプロジェクト

2) 再生医学 ・医療

- ES細胞を重視

・皮膚・骨・角膜など
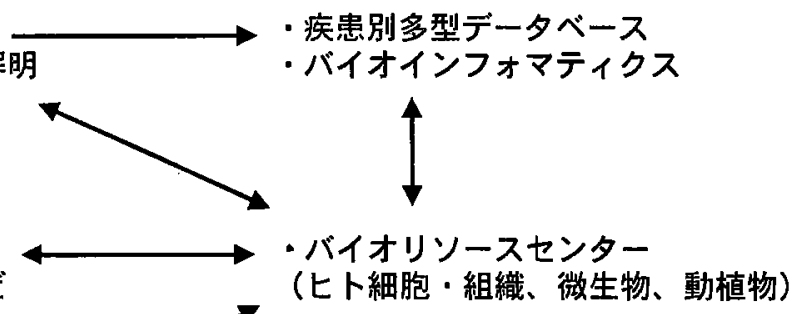

3) がん

脳科学

図 1 ライフサイエンス関連ミレニアムプロジェクト研究 


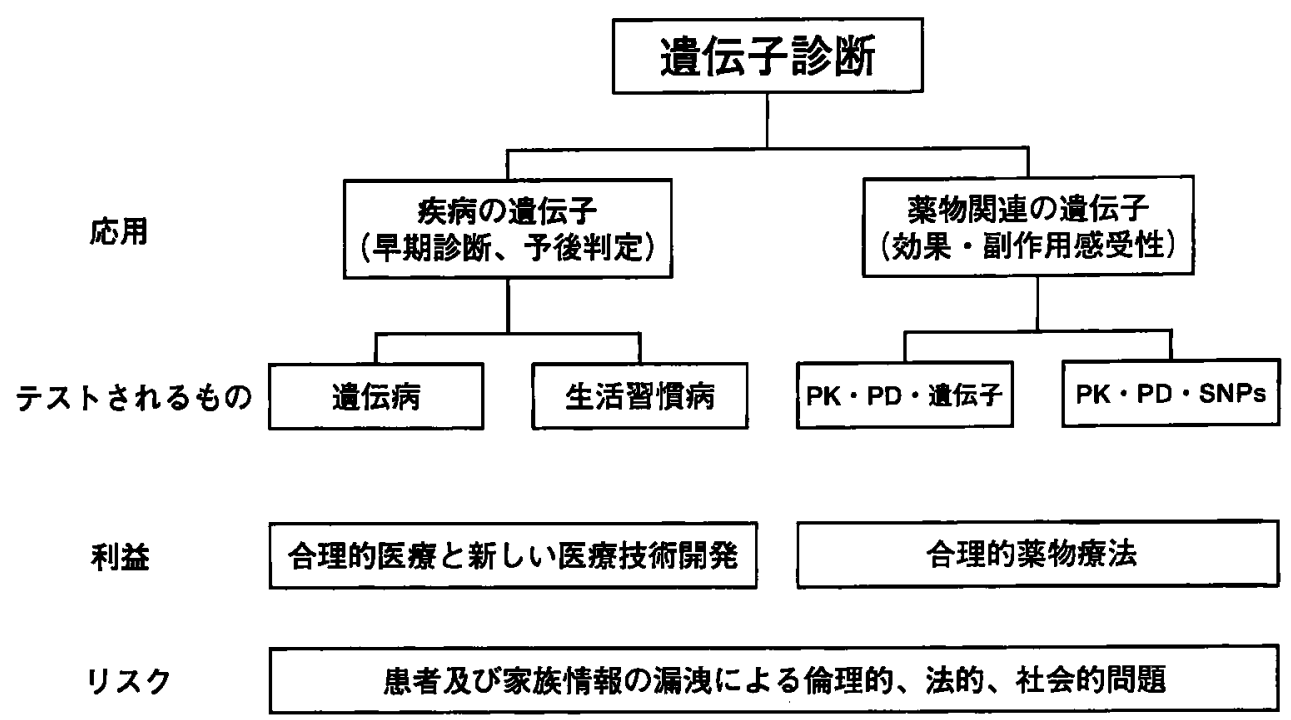

The Lancet, April 15, 2000

図 2

表 4 善玉と悪玉の遺伝子・蛋白・細胞が発見された時の医療へのアプローチ

\begin{tabular}{l|c|l}
\hline & 善玉が見い出されたとき & \multicolumn{1}{|c|}{ 悪玉が見い出されたとき } \\
\hline 遺伝子 & 遺伝子治療 & アンチセンス・デコイ遺伝子 \\
蛋白 & ハイブリッド蛋白 & ヒト化抗体・ワクチン・部位認識医薬 \\
細胞 & 細胞治療・組織工学 & ヒト化抗体・キラー細胞 \\
\hline
\end{tabular}

くなろう. 次に今後進歩の著しい再生医学はまさに才 ーダーメイド医療で，パーキンソン病の治療や角膜移 植などについての細胞治療・再生医学は，すぐにも手 が届きそうな先端医療である.

一方，演者自身は表 4 に示したようにゲノムプロジ エクトで多く発見されるであろう善玉・悪玉蛋白の医 療への応用に興味をもち，そしてそれが重要と考えて いる. 前者の医療への応用に関しては，ハイブリッド 蛋白やDDS 型蛋白の応用が重要であり，これらは演 者の専門でもあるのでいくつかのハイブリッド蛋白の 実際のデータを紹介した，後者については悪玉蛋白に 対するヒト化およびヒト型抗体の作製が重要で，よう やく日本独自で GMP 対応のものができる状況になっ てきた.

次に末だ大きな問題点がある日本の医薬品開発につ いて述べたが，この問題を克服しなければ日本の医療 の進歩も産業の発展も十分に行われないであろう. 箇 条書きで述べると, (1) 極めて画期的なものがない, (2) 新 GCP 対応の治験が依然としてスムーズに行わ
表 5 今後の医薬品開発のひとつのモデル

- 大学 (医療機関含む) における発見

・必要に応じて共同研究（大学主導）

・大学における合成・製䠼作製（委託も含む）

・ベンチャーないしは共同開発（大学主導）

- 薬効薬理, 毒性試験（委託も含む）

- GMP 対応工場での医薬品・製剤の作製

- 第一相試験

・CROによる瀬踏みの第二相試験

・製薬会社と共同開発

れていない，(3) 外国に多くの治験を依頼している， (4) 外国でまず認可をとるものが増えてきている，(5) ブリッジングスタディを活用してもグローバル医薬品 の日本への導入が遅いなどである。

演者はこれらの現状を述べ，さらにその解決策を提 言した。特に瀬踏みの臨床試験（トランスレーショナ ルリサーチ）の一部は大学や研究・医療機関の研究と 捉え, これらの機関の研究者やベンチャーが積極的に 関与してはどうか. 私共もインスリンなどの DDS 製 
版は表 5 に示したようなシステムで行おうと考えてい るので，それを紹介した．日本全体の治験をレベルア ップするのではなく, FDA が認めるような治験がで きるAクラスの治駼施設を 10〜20 数施設早急に整備 してはどうか.
上に述べてきたことに加え，製楽産業などについて 思いきった統廃合などの改革が行われなければ, 日本 のライフサイエンス研究はせっかく政府が大きな予算 をつけても，一部を除き実りあるものにはならないの ではないだろうか。 